\title{
Getting it All in the Right Order: the Love Plot, Trauma and Ethical Uncertainty in Rachel Seiffert's Afterwards
}

\author{
Andrew Monnickendam \\ Universitat Autònoma de Barcelona \\ andrew.monnickendam@uab.cat
}

\begin{abstract}
This article analyzes Seiffert's Afterwards (2007), which, in marked contrast to her debut publication, The Dark Room (2001), has received scarce critical attention. Set in anodyne suburbia, Afterwards narrates the fate of two unglamorous ex-combatants and their trauma. Seiffert's complex narrative binds together romance and PTSD in a double plot that intertwines the fate of a "squaddy" involved in a shooting incident in the Northern Ireland Troubles with that of a former RAF officer stationed in colonial Kenya.

This article argues that beyond subjective issues of judgment, Seiffert shows an awareness that modern romance cannot combine with trauma, as the idea of healing is nonsensical in a world ruled by ethical uncertainty. Furthermore, Seiffert's examination of trauma indicates that in fiction -as in life- author and reader have to confront questions of guilt, responsibility and the absence of forgiveness. Seiffert, drawing on ideas similar to Primo Levi's, concludes the novel with the tragic irony that the more humane the perpetrator, the more distant closure becomes, leaving her main character locked in trauma and the reader ensnared in uncertainty.
\end{abstract}

Keywords: fiction, war, trauma, love-plot

\section{Introduction}

To most readers, an examination of Rachel Seiffert's war fiction would infer her first publication The Dark Room (2001), a collection of three novellas set before, during and after the Second World War. It brought certain fame and prestige; in 2003 she made 
Granta's list of most promising young novelists. The common motif in the three novellas is photography, a resonant echo of Christopher Isherwood's Goodbye to Berlin (1939), the city where the first tale is set. In addition, she takes on board the implications of Isherwood's pronouncement "I am a camera with its shutter open" (7). The phrase suggests that veracity can never be an absolute for the photographer, shifting the onus of interpretation on to the viewer or reader.

Two additional factors provoked interest. In critical terms, The Dark Room was published at a time when photography had already been the subject of in-depth analysis, most notably by Susan Sontag in On Photography (1977) and, two decades later, by Marianne Hirsch in Family Frames: Photography, Narrative, and Postmemory (1997). In other words, what in Isherwood were nuances, suggestions and implications, had, by 2001, been articulated into academic discourse. Furthermore, Seiffert's family background, her German and Australian parents, placed her in that very same community which Hirsch describes:

In my reading, postmemory is distinguished from memory by generational distance and from history by deep personal connections [...] Postmemory characterizes the experience of those who grow up dominated by narratives that preceded their birth, whose own belated stories are evacuated by the stories of the previous generation shaped by traumatic events that can be neither understood nor recreated. (22)

The Dark Room structurally bridges the gap between the two kinds of memory, and attempts, in its final story, to articulate a contemporary case of Vergangenheitsbewältigung -coming to terms with the past. In sum, this first publication had an easily definable way into public attention for both its appealing subject matter and its location within an identifiable critical space.

Although her first book received wide praise, was listed for several literary prizes, and was analyzed in several academic articles, her collection of short stories, Field Studies (2003), and second novel Afterwards (2007), have had little impact and neither has, to my knowledge, been subject to similar attention. In the case of Afterwards, the lack of critical interest might spring from the fact that it avoids the typical subjects of war literature, such as admirable heroism, courageous resistance, or sacrifice. Instead, its subject matter is ignominy, and it remains, as I shall illustrate, a stubbornly elusive text, which is the result of its engagement in the controversy inherent in narratives focused on perpetrator trauma.

My point of departure is that Afterwards has had little critical attention because it cannot successfully bring together a love plot and trauma narrative, a combination that is made even more complex by its double plot. This article, however, will not simply become an extended review, because it recognises that the insolvability of the enigmas presented is recurrent in war fiction, as illustrated by several potent intertextual moments. Afterwards shows an acute awareness of the development of war narratives and a desire to position itself in the contemporary debate such writing has generated.

A brief summary is now provided for those unfamiliar with the text. The character who opens and closes the action is Joseph; the first pages depict him shooting dead a 
suspect in a car at a checkpoint in Northern Ireland during The Troubles; the concluding ones describe how Alice, with whom he has had an uneasy relationship throughout the novel, literally walks out of his life. We could say then that the novel moves from Mars to Venus, but Mars so nearly traumatizes Venus that she wants no part, indeed, all relationships beyond the temporary and the flirtatious are shown as fragile; fulfillment has dropped off the radar. The plot combines this failed contemporary romance with the story of Alice's grandfather David, an ex-serviceman who served in Kenya at the time of the Mau Mau uprising. He is a rather aloof figure, yet his suburban house has acted as Alice's home; in this dysfunctional family, her parents are almost absent during her upbringing. This gap draws trauma and postmemory generations closer at the cost of making the one in-between rather unforgettable and practically irrelevant to the story. During the time that Alice and Joseph's relationship progresses reasonably satisfactorily, she remarks that her grandfather is thinking of redecorating his home; as Joseph is a painter by trade, he takes on the job. Both ex-servicemen have a lot in common and get on well to begin with. Seiffert then employs one of her favorite narrative strategies: to draw an apparent parallel that turns out not to be one at all; the dissimilarities outweigh the similarities. In this case, reminiscence makes David more loquacious and likeable, able to overcome trauma through expressing it, whereas Joseph becomes increasingly taciturn, uncommunicative and eventually violent. He wrecks the decorating job, manically hurling paint everywhere. For Alice, reconciliation with Joseph becomes impossible; he is left alone with his memories.

The book was not as widely reviewed as The Dark Room. This selection of its early reception shows that it radiated a certain degree of perplexity, perhaps because adapting the Isherwood approaches, it places a considerable burden on its readers. No clearer example is shown by The Guardian when it affirmed that "[e]ach sentence is stripped to its bare minimum and often beyond, and there is a notable lack of description that makes it difficult to engage emotionally with the characters [...] Although occasionally lacking the sophistication one might hope for, it provokes questions, even if some are without answers" (Segal). The Independent wrote that "[c] onversational boundaries are vague, with reported speech mingling with direct speech and internal monologue. Sometimes it can be confusing, but the technique shows that sometimes it is unclear just what has been said" (Guest). These two examples are hardly enthusiastic; in both cases the review expresses the opinion that the 2001 volume was better. More laudatory was The New York Times reviewer, Kathryn Harrison, herself a novelist, who wrote that "her prose functions as a camera might, with the added power to reveal unvoiced thought as well as dialogue [...] her characters' internal reflections seem utterly authentic, never devolving into the inconsequential babble often presented as stream-ofconsciousness" (Harrison). What all reviews share is the belief that one outstanding feature is the novel's enigmatic nature, whether this is considered slightly confusing, engaging, or just a true reflection of the nature of human relationships. In short, the novel, to differing degrees, bewildered its reviewers. 


\section{Setting up the parameters}

The epistemological problems are introduced in the novel's early chapters. The reviews highlighted Seiffert's clipped style, but that does not necessarily convey how radically she goes about her task, as is evident from the opening scene:

Winter afternoon, five hours patrolling, seventeen minutes on the vehicle checkpoint and counting. Rain. Two cars, two drivers: one man, one woman. She was in the white car, three children with her. One adult passenger, male, in the other car, the red one. One multiple: four men on the rise, four in the fields, and four on the road. Two us by the first car, two by the second. One round fired. (3)

This minimalist narrative -verbless sentences, one word-sentences- builds up to what is -no pun intended- the trigger moment: "one round fired". The rest of the book unravels the consequences of that one round. Such writing obeys a mimetic imperative, namely that a passage that requires only a few seconds to read corresponds to the split second in which decisions are taken and events are played out, putting into doubt whether agency is really an adequate term in such circumstances. In addition, such minimalism reflects Jane Seaton's point that it appears "as if memory works better with frozen images" (102). For Joseph, using Seaton's terms, the event is a "reality death" (185), whereas for the reader it is just a statistic, the distinction being that the former has a history and content, whereas the latter is simply a mere number, communicating little if anything at all. It therefore lacks drama and trauma, conveying neither information nor feeling.

The incident is followed by Joseph's debriefing, a process which, if successful, would lessen if not extinguish trauma. Yet debriefing is a word of some complexity on which I would like to dwell momentarily. The Chambers Dictionary states that the verb means "to gather information from a soldier or astronaut, etc, on return from a mission" (435), the affix, "indicating a reversal of process, or deprivation" (432), in this case concerning the verb brief, meaning "to give information or issue instructions to" (208). However, in what seems an extraordinary case of Freudian Unheimlichkeit, brief and debrief start off as dictionary opposites and fall into each other. That Joseph yields information to his superiors is not in doubt, but what dominates the second scene of this opening chapter is anxiety and confusion: "it was hard to get it all in the right order" (Seiffert, 3). The implications and outcome of this linguistically simple, almost monosyllabic sentence, become Joseph's insoluble problem. Bit by bit, it becomes clear that he is the person to whom instructions are being given: "Draw it. Birds-eye view" (5). The debriefing turns into a cross-examination, and his failure to articulate what he has witnessed and participated in reads more like the accused undergoing interrogation for a crime -hence the ambivalent presence of an army solicitor- than anything else. It would be a relatively simple task to give the process an overtly political reading: the soldier is shown just to be a number, just a dehumanized general issue rather than a person. More specifically, we could maintain that British policy molds events to suits its policy of forced occupation in Northern Ireland therefore compelling Joseph to accept 
the official account. This is not the case, as the officers try to obtain full details of what is going on and hence reduce the possibility of long-lasting trauma on a person who, militarily, was simply doing his job. In short, just as briefing and debriefing collide into each other, so do trauma and the avoidance of trauma, because the debriefing fails miserably in its aim to assist. We are therefore brought to a situation which has been lucidly described by Eric L. Santner in his account of narrative fetishism, which he defines as "the construction and deployment of a narrative consciously or unconsciously designed to expunge the traces of the trauma or loss that called the narrative into being in the first place" (144). Furthermore, the passage shows that at this point Joseph is inarticulate because he is incapable of describing his experience; he is therefore asked to draw, as if that were simpler! Surely, the verbal sparseness of the text indicates that the mind is unable to function so soon after the traumatic moment. This episode can be envisaged both as descriptive and as a lengthy exploration of the malleability of language, a strategy which the narrative extends to two key concerns, the love plot and trauma, terms whose meaning drifts back and forwards from the certain to the inexact.

Immediately afterwards, the double plot begins. It takes us to a completely different literary landscape via David's memory of the Mau Mau campaign (1952-1960). He took part in the bombing of the Aberdare Mountains, the Kikuyus' homeland. Extending the use of resonant numbers, the narrative reveals that David did not fire one single round but "five five-hundred-pound bombs and five one-thousand-bombs" (7), a far deadlier cargo. The use of numbers welds the two plots together. Seiffert makes two further significant links or comparisons. First, the presence of a spotter in the plane, the flares, added to the fact that David notes that "[i]t was too dense to see much, the forest" (8), ensure that he never witnesses the outcome: he can only imagine what might have happened, which may or may have not been of much consequence. Paul Fussell, for example, makes it very clear that the claim for the accuracy of precision bombing has always been vastly exaggerated. Writing about World War Two, he states that it "became a comical oxymoron relished by bomber crews with a sense of black humor" (14).

The second move occurs at the moment intertexuality enters the scene: Seiffert's landscape is deeply reminiscent of Joseph Conrad's iconic Heart of Darkness:

Once, I remember, we came upon a man-of-war anchored off the coast. There wasn't even a shed there, and she was shelling the bush. It appears the French had one of their wars going on thereabouts [...] In the empty immensity of earth, sky, and water, there she was, incomprehensible, firing into a continent. Pop, would go one of the six-inch guns; a small flame would dart and vanish, a little white smoke would disappear, a tiny projectile would give a feeble screech -and nothing happened. Nothing could happen. There was a touch of insanity in the proceeding, a sense of lugubrious drollery in the sight; and it was not dissipated by somebody on board assuring me earnestly there was a camp of natives -he called them enemies!- hidden out of sight somewhere. (40-1)

It would be difficult to maintain that Seiffert was not recalling this highly iconic description. It comes from different century, it describes a different form of war (naval 
in the case of Conrad), but in both circumstances bombardment into the invisible forest assumes that the colonial enemy is "hidden out of sight somewhere". With the use of such terms as "incomprehensible", "a touch of insanity", the Conradian narrative expresses a value judgement, whereas Seiffert's non-committed voice refrains, and whether David or the text as a whole shares similar views on war remains to be seen. Seiffert's Conradian opening projects its dark shadow over the rest of the Seiffert's exploration of horror: neither text will generate catharsis. Subsequently, the novel is not simply an account of contemporaneity but one that is keenly aware that there are literary ancestors and representational difficulties that stretch back over time.

\section{The love plot}

The hermeneutic uncertainty in Afterwards stems from the love plot, as the novel shifts between the conventions of romance and post-trauma, two genres that do not easily match. Although it is outside the scope of this paper to undertake a thorough account of the subject, some contextualization is necessary. De Rougemont's highly influential hypothesis, expressed at the opening of his classic L'Amour et l'Occident (1939), that happy love has no history, is based on the solid foundation that Western archetypes are essentially tragic, as passion is located outside marriage, the consequences thereafter are predictably fatal. In contrast, much mainstream fiction resists such pessimism and champions the value and possibility of love-in-marriage, even if this is achieved -in the time-honored style of Jane Austen and the great Victorian triple-deckers- at the expense of omitting post-marriage scenes. In To the Lighthouse, one of Virginia Woolf's characters ruminates "that the whole of life did not consist in going to bed with a woman" (162), a view which seemingly reflects Woolf's uncompromising views, as set out in her 1919 essay on modern fiction. She insists that the modern novel should contain no distracting love interest. It would be fair to place Seiffert close to this skeptical school of thinking.

However, Seiffert is writing almost a century after Woolf, so other factors must play a role too. I would propose the following: first, the fact that libraries, publishers, bookshops, and Amazon catalogue "fiction" as distinct from "literary fiction" indicates a significant difference between fiction in which the love plot often plays a vital role and fiction where it does not. Second, I am aware that that sounds like a sweeping generalization; nonetheless, it is true that the love plot features little in criticism of the contemporary novel. A representative example is provided by Richard Lane, Rod Mengham and Philip Tew, who divide their influential Contemporary British Fiction (2003) into four sections, "Myth and History", "Urban Thematics", "Cultural Hybridity", and "Pathological Subjects", a division that shows that other concerns are of greater importance. In the introduction, it is stated that "[a]n alternative template, in which the organizing tensions of the writing are still primarily psychological in their mode of operation, comes from the historical version of Oedipal conflict" (4), in other words, the contemporary writer wants to kill not Sigmund Freud but the influence of 
critical and novelistic forerunners. A similar lack of interest in the love plot is evident in other studies, such as Tew (2004), Head (2002), Hutchinson (2008) or Driscoll (2009).

If the explanation is Oedipal, Anita Brookner, whose novelistic career is almost exclusively focused on the examination of female desire and the love plot, has a lot to answer for. A Start in Life begins with a declamatory pronouncement that "Dr Weiss, at forty, knew that her life had been ruined by literature" (7). In other words, she has been greatly damaged by the misinformation enclosed in the love plot, a situation exacerbated by her career as literary scholar. Throughout the novel she suffers the consequences that belief in it ineluctably produces to such an extent that even at closure she is unable to make a start in life. Brookner's all-engaging self-referentiality suggests that literary fiction should deal with other matters.

Third, current philosophical inquiries shed light on the subject, particularly the recent work by Byung-Chul Han (2012). He argues that the erosion of the other, which is basically the consequence of the Narcissism of the digital age, reduces if not eliminates the figure of the lover and the concept of eroticism; pornography inexorably extends its influence. This does not completely match the situation here, but Seiffert depicts a society that has likewise exiled Eros to its margins.

This is well illustrated in approaching the episode in Afterwards that is the closest to emotional or physical fulfillment; in line with Han, the impossibility of knowing the other becomes apparent. Joseph and Alice's time together, I doubt we could call it happiness, is spent on a walking holiday in Scotland: there is mention of granite houses and the memory of ceilidhs. They spend their last night together at a B \& B, which Joseph describes as "damp [...] but peaceful".

They stayed late in the pub next door, but Alice wasn't tired when she got into bed. other Felt the loss of her: permanent, final. She dozed and then later she cried. Tried to be quiet about it, though Joseph was sleeping in the other bed. But then he reached over in the dark found the crook of her arm, rested his fingertips there. A bit later he took her hand and held it until she stopped crying, and longer. It wasn't what she expected, Joseph didn't come into her bed, but it was gentle, soothing somehow, and Alice was grateful to have him lying awake with her. They got up with the alarm for the first time in a week and dressed slowly, without speaking. Handing stray socks and jumpers across the beds to one another, packing and tidying. Sun just rising and they could see each other in the half-light, both puffy-eyed. (160)

They are puffy-eyed, a condition that could equally be the upshot of stress or a hangover. A parallel is apparently being drawn between Alice's sadness and Joseph's trauma: in this instance, she suffers, she cries, she cannot sleep, but again this is just another situation where initial convergence cedes to divergence. Surely, a comparison between moments of sadness caused by memories of a dead relative and Joseph's PTSD is completely disproportionate. At this particular juncture, tenderness is evoked by Alice finding comfort in Joseph's caresses, by the exchange of the stray clothing, and other details that hover between affection and despair, as little more can be expected 
from human relationships. This is precisely the knowledge Brookner's Dr Weiss did not secure.

The Alice-Joseph relationship is paralleled by David's marriage to Alice's grandmother, itself a second marriage, and consequently a highly unconventional one for its time and place.

Alice couldn't believe he [David] had nothing to tell: he'd fallen in love with a married woman at a time when divorce was still considered scandalous. His superiors admonished him, his friends in the air force advised him to end the affair. His parents refused to come to the wedding, and didn't speak to him for years because he went ahead regardless. (108)

Of course, what gives the marriage a romantic sheen, for Alice at least, is the colonial setting in Kenya, in her view, a much more exotic place than deepest suburbia or County Armagh. The narratives are stitched together by a series of mirror-like patterns, such as having them sitting in the suburban garden while David recalls the Nairobi garden (118); by passing remarks which certainly have a wider significance than their apparent banality, for example, "things out there were familiar and unfamiliar at the same time" (118); by Joseph hearing David describe his recovery from serious illness as "a lonely business" (119), an epithet which describes his own personal circumstances; and by David marrying a divorced women while Joseph's relationship with Alice is his second serious affair. These -added to other parallels- are too numerous and thematically similar to be unpremeditated or to pass unnoticed, but there is a major dissimilarity: while David's move to suburbia with Isobel, the woman he loves, enables him to lead a reasonably sane life, such comfort will remain completely out of Joseph's reach. Although the double plot draws the two couples together, it also highlights their differences. Why love, desire or eroticism have no restorative power for Joseph is not articulated within the fictional context and therefore remains one of the novel's many disheartening enigmas. The most logical explanation is that more time is required for Joseph to reach a situation similar to David's, but however much that might respond to common sense or knowledge of psychology, it is not an interpretation that the text itself yields.

Where does an apparently lacklustre plot in a severely lustless novel leave us? The deliberate lustlessness accentuates the novel's concern with a series of issues surrounding both the modern love-plot and questions of guilt and responsibility in postwar scenarios. In Essays in Love, written in his inimitable hybrid style mixing fiction and philosophy, Alain de Botton's narrator expresses the following principle:

With the modern love affair, the adventure loses its hegemony, what happens can no longer be a reflection of the character's inner states. Chloe and I were moderns, inner monologuers rather than adventurers. The world had been largely stripped of capacities for romantic struggle $[\ldots]$ sex was a duty, not a crime. (132)

The consequence of this is that the therapeutic "night duty" depicted in Hemingway's A Farewell to Arms, (the nexus of wounded soldier-hospital bed- 
Catherine Barkley), forms a completely different setup through its adherence to traditional tropes of desire within the De Rougemont parameters: the tragic love plot holds ground, modified, arguably in this instance, through an incongruous vision of gender and sexuality. Seiffert, it must be noted, is bleaker in her outlook than either Hemingway or de Botton, as the notion of a common history is something that the couple really does not have, reducing the cachet of sexuality to a bare minimum and heightening the importance of "inner monologuers" as surrogate. The past remains another country and the present an uncharted one. Seiffert's couple seem so distant that they do not even get involved in what de Botton calls romantic terrorism, that is, the constant vigilance of the partner's actions and words that reads any suspicious remark or gesture as proof of unfaithfulness. If they have become "inner monologuers", they will never communicate meaningfully. Indeed, the word couple, too, has been emptied of its meaning. My first major conclusion therefore has to be that Seiffert judges the love plot to be irrelevant in modern narratives of war and its aftermath. It neither heals the warrior's wounds nor has any beneficial or restorative function.

\section{Trauma}

David only starts talking after meeting Joseph. We are told -in a sentence which reads like a perfect metonym for trauma- of Joseph's opinion of David's account of colonial life: "His small head must have been full of it" (143), an echo of Joseph's difficulty, "it was hard to get it all in the right order" (3), to which I referred previously. Whereas David is able to relive his earlier life and expurgate his sins, Joseph's head is so full of it that the following pages, dedicated to his experience in Armagh, show that memory surfaces as nightmare rather than exorcism.

Joseph does externalize his anger and frustration shortly afterwards, in chapter eleven, which is again structured along the line of previous ones, that is to say, by the juxtaposition of seemingly similar events with scarce if any judgment from the narrator. From the first incident, a conversation between Alice and her mother, we learn that David's Conradian account of firing into the jungle is a white lie. In fact, he was involved in an extremely dramatic incident of what is euphemistically called "[s]ympathetic detonation" (239). An aerial bomb detonated too early, causing all the other bombs to detonate (sympathetically) with such devastating circumstances that, with the bomb-bay still open, shrapnel ripped its way through David's plane. With an emphasis that tries to widen conceptions of witnessing beyond the purely visual, David hears "everything" (239), while a flight engineer bleeds to death. David had previously only told his wife about it; the fact she was a nurse by profession is perhaps rather too overt symbolism. To a certain extent, Joseph has acquired that function, for this reason David apologizes for "running on the way I have" and admits "I used to talk about it with her" (243). While Joseph remains silent, he then proceeds to chatter for a lot longer about his own personal happiness during these years, mixing feelings of guilt with 
lingering incomprehension of certain events. Once David has left, Joseph hurls paint everywhere:

The old man must have heard it all but he never came back. Joseph stood at the door with the shock of what he'd done. Cold, outside air filling the hallway. Paint flung across the floor and walls and the windows and seeping into the carpet. (251)

There is nothing problematic here, as such displacement of wartime rage has its roots in classical literature, from Achilles onwards. David is aware that his own stream of consciousness has triggered off an emotional outburst, another sympathetic detonation, and as before, he will not witness, but will again hear everything. His empathy, his awareness of trauma in another ex-combatant, explains his refusal to blame Joseph at all; he is conscious that his own recovery has come at the cost of precipitating another person's breakdown.

The rest of the novel deals with Joseph's fruitless attempt to expel his sense of guilt, unaware that David achieved this desirable goal only decades later. Joseph talks to his former Corporal but gets no relief, even when it is made abundantly clear that everyone in the car was armed. The argument that the British Army was at war with the IRA goes into one of Joseph's ears and straight out of the other. We are told that his former girlfriend could not tolerate his long periods of moodiness and introspection: "Just a substitute. Fucking for talking. No good having one without the other" (290), she laconically tells him. Venus will never ever overcome Mars, a premise that becomes gains credibility when Joseph and Alice have their final encounter. After a mundane conversation, she gets up, and walks out of the door without looking back; it is perhaps unnecessary to add that forgiveness at one minute before midnight is a quite common cultural cliché. Even the motif of sight, watching and witnessing falls away; she will not even look at him. In short he is back to square one if not even farther back than before, as Alice's family are probably going on a trip to Africa to revisit past scenes. They have bonded.

\section{Death, Guilt and Responsability}

Ruth Kluger's Landscapes of Memory: A Holocaust Girlhood Remembered begins:

Their secret was death, not sex. That's what the grown-ups were talking about, sitting up late round the table [...] I wanted to get in on the forbidden news, the horror stories, fascinating though incomplete as they always were - or perhaps even more fascinating for their opaqueness, that whiff of fantasy they had about them, though one knew they were true. Some were about strangers, others were about relatives, all were about Jews. (3)

The passage describes a realistic representation of awareness of what is, in this instance, both an estrangement of sexual knowledge and the presentation of the real taboo subject in Kluger's case: deportation and mass murder. Seiffert's novel adds 
weight to the argument that the "secret" of modern times for adults is once again, death. This is also borne out in recent Man Booker prize winners, such as Hilary Mantel (2009 and 2012), Howard Jacobson (2010) or Julian Barnes (2011), whose central subject is decline and death, whether in Tudor times or the present day. Again, Seaton is particularly eloquent on the subject. How ironic it is, she states, that "in a century in which the developed world seeks more than ever to keep any direct experience of physical violence at arm's length, images and representations of violent behaviour have become harder to escape than at any previous time in history" (287). Yet her emphasis on the strict constraints on reporting have been contested. Violence, it would seem, does make news, or in Jean Baudrillard's terms, "[t]he media promotes the war, the war promotes the media" (31), nonetheless his demotion of action to staginess approaching virtual reality is less convincing than Seaton's detailed account of what may and may not be shown.

Such existential bleakness may be temporarily pushed to one side if we concentrate on the interconnected questions of guilt and responsibility. In this passage, Primo Levi is very plainspoken:

The memory of a trauma suffered or inflicted is itself traumatic because recalling it is painful or at least disturbing [...] Here, as with other phenomena, we are dealing with a paradoxical analogy between victim and oppressor, and we are anxious to be clear: both are in the same trap, but is the oppressor, and he alone, who has prepared it and activated it; and if he suffers from this, it is right that he should suffer; and it is iniquitous that the victim should suffer from it, as indeed he does suffer from it, even at a distance of decades.

Levi's unshakeable conviction that an oppressor remains an oppressor, and the victim a victim not solely during the act of torture but for ever, is a response to the growth of ethical relativeness, a situation which the text ostensibly tries to avoid. The Drowned and the Saved was first published in 1986, and may have exercised an influence over Seiffert's novel, but if that is not the case, they undoubtedly share similar concerns. Afterwards recounts the experience of two oppressors during several stages of their attempted but inevitably doomed wish to live as free from recall as possible. The double plot's inextricable threads suggest that each story reflects on the other, despite their radically different conclusions. David has as happy an ending as possible: he has become relatively human, whereas Joseph has got nowhere on the road to recovery or to coming to terms with his military past.

The question that leaves us with is whether Seiffert's novel appraises the Levi template, concluding along the same lines that it is right that Joseph suffers. This is a distinct possibility, due to Seiffert's keen sensibility to official discourse and its nuances, revealing examples being the exploration of brief/debrief, or the ironical significance of sympathetic detonation. Joseph, both in his debriefing and in the encounter with his corporal, is told more or less the same thing: that he has done his duty. Peter Haidu's analysis of Nazi language and particularly a speech by Himmler provides interesting evidence. He argues that the "desubjectification of the victim was a 
programmed precondition for his or her victimization, a precondition enabling the perpetrators' enactment of the narrative program of exterminations" (291). One death in Armagh is a long way from the holocaust, yet there is a similarity. Joseph feels guilty because he is aware that the process of desubjectification does not function. He does not accept that the victim was either, in human terms, simply someone out to get him, or else, a desubjectified being. To say that Seiffert is hard on Joseph is to completely miss the point. Joseph's suffering derives precisely from both the medical awareness of "long term effects on personality and adjustment" (Joseph et al., 2) and also from the creative insight and irony that it is his humanity -his refusal to see death as an inevitable outcome or as a statistical item - that torments him. In short, he suffers because he cannot envisage his action as other than bringing about what is, in Seaton's terms, a reality death. David, in contrast, is able to function properly because he never saw the Mau Mau -in the most literal sense of the word, they were either hidden by dense foliage or not there at all- hence he does not imagine them as life-threatening, which would inevitably facilitate their desubjectification. This is why, ironically, David looks more kindhearted than Joseph; the former's increased sociability is the result of an ambivalent stance towards death which Joseph's humanity will not provide him with. This is a very cruel situation, but it is a completely coherent one. As a consequence, redemption and forgiveness have become immaterial.

The sparseness of Afterwards brings to the fore the whole subject of witnessing. Bernard-Donals and Richard Geljzer, picking up on Levi's awareness of the "selfconsciousness of the written witness" (60), argue that written memoirs, due to their plasticity, afford the witness the possibility of redefining reality. Oral testimony is qualified by different phenomena, the first is the knowledge that the record is destined for posterity, which conditions the witness's discourse. In any case, they add, the reporter and witness are separated by a "vast imaginative space" (73). Consequently, Bernard-Donals and Geljzer emphasize the importance of gaps, stutters and hesitance, namely those parts of speech that lack a denotation and which will remain stubbornly inaccessible to their audience; they "can only be glimpsed" (58). Afterwards shows exactly that awareness of the nature of memory, and subsequently bases its portrayal of Joseph principally on glimpses, gaps, stutters and hesitance. Only David, for having lived through a similar situation, is capable of turning pointers of inarticulateness into fuller meaning. What distinguishes the two characters is specifically the extent to which David himself learns how to fill the gaps, even if this costs Joseph his sanity. Levi's forceful assertion that torturers suffer and deserve to do so is therefore not put in doubt by Seiffert's text at any moment, a pointed rejoinder to the ethical vagaries of Bernhard Schlink's hugely successful The Reader (1997). On the contrary, the fact that we can analyze the reasons for Joseph's trauma while simultaneously acknowledging that he will not possess a successful exit strategy is indeed the reason why there will be no closure. Hayden White, in his discussion of Woolf, argues that "literary modernism was a product of an effort to represent a historical reality for which the older, classical realist modes of representation were inadequate" (51). This can be extended, as it is surely the case that in the line of succession, the Seiffert style, informed by postmemory, informed 
by our better understanding of PTSD, is also aware of the dangers of a Baudrillardian approach to conflict in which the discursive and virtual play such an important role, and, mistakenly or otherwise, whittle away at questions of responsibility and guilt. Conceivably, in Seiffert's text, such an approach would become the ultimate form of literary fetishism in a viewing society; for this reason, I conclude that Joseph must be seen to suffer, as it is ethical that he should do so. This is why Seiffert designs her book on misleading parallels, as the text continually asks us to judge to what extent war and trauma should be approached through contrastive analysis. In the end, following Levi's template, such an approach is seen to be toxic, because it looks askance at the key issues. It contributes nothing to our understanding of trauma, or, as the case of Joseph shows, just makes matters worse.

\section{Conclusion}

In closing, I believe it is necessary to answer a question that readers of this article might have been asking themselves: it is really acceptable to constantly back up arguments about Afterwards by reference to Holocaust studies? In a recent article, Sue Vice stated, "Others [commentators] may follow the view that to understand or analyze a perpetrator perspective is to exonerate or to encourage inappropriate identification" (15), and clearly a combatant involved in bombing in a colonial war or a "squaddy" who shoots a suspected member of the IRA are irrefutably perpetrators who suffer from "perpetration-induced traumatic stress (PITS)" (22). Seiffert is a writer whose work, by moving from Germany in World War Two to Britain at the time of The Troubles, invites us to consider such teasing problems. Is Seiffert really trying to extend Holocaust parameters to conflicts recounted in Afterwards? As I have noted, Seiffert's pared-down narration is one strategy which makes it difficult if not impossible to discover if the narrative voice or author herself has identifiable views on perpetrator trauma that would enable us to articulate a convincing judgement about the text's ethical and moral polemics. The problem can be framed in the following question: given that the text focuses on two heads which are so "full of it", does that imply that these are two variations on the same theme?

I would argue that the highly detailed account of their case history makes the jump from the individual to the general impossible without recourse to speculation on issues the text itself does not engage with. Therefore, Seiffert's withdrawal of sympathy from her characters, rather than serve to link the events her characters are involved in to holocaust literature or the shadow of Conrad, contributes to separation, thus reinforcing the specificity of colonialism and the uniqueness of the Holocaust. This becomes, therefore, a perfectly coherent warning about potential intellectual incoherence, what we perhaps could call critical relativism. Seiffert's text thus adheres closely to Primo Levi's reiterated beliefs in the dangers of exoneration, also outlined by Vice, but that proximity does not make for engaging reading: at the risk of repetition, the double plot resists, more than encourages, a contrastive approach. Joseph found it impossible to put 
things in order, just as the reader has to untangle questions that cannot be solved by a loose comparison to others with enticingly similar structures but different histories and contexts; the latter are much more important than the former. Specificity must be the decisive factor, else we confront the danger of drawing misleading parallels, or what is, to adopt Seiffert's use of military terms, a sympathetic detonation.

\section{References}

Baudrillard, Jean (1995): The Gulf War Did Not Take Place. Trans. and Intro. Paul Patton. Bloomington: Indiana UP.

Bernard-Donals, Michael and Richard Glejzer (2001): Between Witness and Testimony: The Holocaust and the Limits of Representation. Albany: State University of New York Press.

Brookner, Anita (1991): A Start in Life. Harmondsworth: Penguin.

De Botton, Alain (1994): Essays in Love. London: Picador.

Byung-Chul, Han (2012): Agonie des Eros. Berlin: Matthes \& Seitz.

The Chambers Dictionary (1995): Edinburgh: Chambers Harrap.

Conrad, Joseph (1987): Heart of Darkness. Harmondsworth.

Driscoll, Andrew (2009): Evading Class in Contemporary British Literature. Basingstoke: Macmillan.

Fussell, Paul (1989): Wartime: Understanding and Behavior in the Second World War. New York and Oxford: Oxford UP.

Guest, Katy (2007): "Afterwards by Rachel Seiffert, Guilty Secrets". The Independent. Web $(02 / 02 / 2007)$.

Haidu, Peter (1992): "The Dialects of Unspeakability: Language, Silence and the Narratives of Desubjectification". In Saul Friedlander, ed., Probing the Limits of Representation. Nazism and the 'Final Solution'. Cambridge MA: Harvard UP, 277-99.

Harrison, Kathryn (2007): "Truth and Consequences". The New York Times. Web. $(12 / 08 / 2007)$.

Head, Dominic (2002): The Cambridge Introduction of Modern British Fiction, 1950-2000. Cambridge: Cambridge UP.

Hirsch, Marianne (1997): Family Frames: Photography Narrative and Postmemory. Cambridge MA: Harvard UP.

Hutchinson, Colin (2008): Reaganism, Thatcherism and the Social Novel. Basingstoke: Macmillan.

Isherwood, Christopher (1969): Goodbye to Berlin. Harmondsworth: Penguin.

Joseph, Stephen, Ruth Williams, and William Yule (1999): "Post-traumatic Stress Disorders in Adults". In William Yule, ed., Post-Traumatic Stress Disorders. Concepts and Therapy. Chichester: John Wiley, 1-24.

Kluger, Ruth (2003): Landscapes of Memory: A Holocaust Girlhood Remembered. London: Bloomsbury.

Lane, Richard, Rod Mengham, and Philip Tew (2003): Contemporary British Fiction. Cambridge: Polity Press.

Levi, Primo (2000): The Drowned and the Saved. London: Abacus.

Santner, Eric L (1992): "History beyond the Pleasure Principle: Some Thoughts on the Representation of Trauma". In Saul Friedlander, ed., Probing the Limits of Representation. Nazism and the 'Final Solution'. Cambridge MA: Harvard UP, 143-154. 
Seaton, Jean (2005): Carnage and the Media. The Making and Breaking of News About Violence. London: Allen Lane.

Segal, Francesca (2007): "Alice is no Longer in Wonderland". The Guardian. Web. $(14 / 01 / 2007)$.

Seiffert, Rachel (2007): Afterwards. London: Vintage.

Tew, Philip (2004): The Contemporary British Novel. London: Continuum.

Vice, Sue (2013): Exploring the Fictions of Perpetrator Suffering. Journal of Literature and Trauma Studies, 2(1-2): 15-25.

White, Hayden (1992): "Historical Emplotment and the Problem of Truth". In Saul Friedlander, ed., Probing the Limits of Representation. Nazism and the 'Final Solution'. Cambridge MA: Harvard UP, 37-53. 